JIPS, Vol. 2 No. 1

Halaman: 12 - 17

Mei 2021
Jurnal Inovasi Pembelajaran di Sekolah

DOI: https://doi.org/10.51874/jips.v1i01.8

ISSN 2774-9363 (Cetak)

ISSN 2774-9746 (Online)
JIPS

Jurnal Inovasi Pembelajaran di Sekolah

\title{
Pendampingan Siswa pada Program Belajar Dari Rumah untuk Membangun Semangat Siswa Sekolah Dasar di Desa Pekalongan Kecamatan Winong Kabupaten Pati
}

\author{
Indah Puji Lestari, Veryliana Purnamasari, Iin Purnamasari \\ Program Studi Pendidikan Guru Sekolah Dasar, Universitas PGRI Semarang \\ Email: indahpuji984@gmail.com
}

\begin{abstract}
Abstrak
Desa Pekalongan adalah sebuah desa yang ada di Kecamatan Winong, Kabupaten Pati, Provinsi Jawa Tengah Indonesia. Kegiatan Kuliah Kerja Nyata (KKN) yang dilaksanakan mulai 26 Januari sampai dengan 26 Februari 2021, Berdasarkan data yang diperoleh Desa Pekalongan memiliki kondisi, potensi, dan permasalahan yang berbeda-beda seperti adanya permasalahan yang dirasakan siswa SD, SMP, SMA yang terdampak adanya Covid19 menjadikkannya mau tidak mau siswa-siswi memberlangsungkan program belajar dari rumah. Kuliah Kerja Nyata (KKN) merupakan bentuk kegiatan pengabdian kepada masyarakat yang bersifat khusus, karena dalam KKN darma pendidikan dan pengajaran, penelitian serta pengabdian masyarakat dipadukan kedalamnya dan melibatkan sejumlah mahasiswa dan sejumlah staf pengajar, serta unsur masyarakat. Berdasarkan hal tersebut mahasiswa KKN Universitas PGRI Semarang tidak terlepas fungsinya sebagai mahasiswa pendidikan, diharapkan dapat menyalurkan ilmu atau pengetahuan yang didapat dari bangku perkuliahan kepada orang lain. Teknik pengumpulan data yang digunakan dalam artikel ini ialah pendekatan partisipatif (participatory approach), untuk memberikan gambaran tentang kegiatan pendampingan belajar dari rumah untuk membangun semangat siswa sekolah dasar di Desa Pekalongan Kecamatan Winong Kabupaten Pati. Sehingga artikel ini bertujuan untuk kelangsungan dalam memahami fenomena pendampingan belajar dari rumah yang terjadi secara holistic (utuh) terkait untuk membangun semangat belajar siswa sekolah dasar dengan cara deskripsi analisis secara induktif dalam bentuk kata-kata dan bahasa.
\end{abstract}

Kata kunci: pendidikan, pendampingan belajar, belajar dari rumah

\begin{abstract}
Pekalongan Village is a village in Winong District, Pati Regency, Central Java Province, Indonesia. The Real Work Lecture (KKN) activity which was held from January 26 to February 26, 2021, Based on data obtained, Pekalongan Village has different conditions, potentials, and problems such as problems felt by elementary, middle, and high school students who are affected by Covid -19 makes it inevitable for students to carry out learning programs from home. Real Work Lecture $(\mathrm{KKN})$ is a form of community service activity that is special, because in $\mathrm{KKN}$, education and teaching, research and community service are integrated into it and involve a number of students and a number of teaching staff, as well as elements of the community. Based on this, the KKN PGRI Semarang University students cannot be separated from their function as education students, they are expected to be able to distribute the knowledge or knowledge gained from the lecture bench to others. The data collection technique used in this article is a participatory approach, to provide an overview of learning assistance activities from home to build the enthusiasm of elementary school students in Pekalongan Village, Winong District, Pati Regency. So this article aims to continue to understand the phenomenon of home learning assistance that occurs holistically (whole) related to building the learning spirit of elementary school students by means of inductive analysis descriptions in the form of words and language.
\end{abstract}

Keywords: education, learning assistance, learning from home 
PENDAHULUAN

Desa Pekalongan adalah sebuah desa yang ada di Kecamatan Winong, Kabupaten Pati, Provinsi Jawa Tengah Indonesia. Desa Pekalongan merupakan salah satu dari 30 desa di Kecamatan Winong Kabupaten Pati Provinsi Jawa Tengah, yang berlokasi di sebelah tenggara dari pusat Kota Kabupaten Pati dengan jarak tempuh kurang lebih $17 \mathrm{Km}$. Desa Pekalongan terletak di posisi yang sangat strategis, yaitu di jantung Kecamatan Winong. Letaknya berdekatan dengan pusat Pemerintahan Kecamatan Winong, berdekatan dengan pusat bisnis di Kecamatan Winong, dan berada di titik penghubung 4 (empat) kecamatan, yaitu Kecamatan Winong, Kecamatan Gabus, Kecamatan Pucakwangi dan Kecamatan Jakenan. Kepala Desa Pekalongan bapak Ukhwatur Roi, S.Pd.I. sedangkan ketua RT 04/ RW 02 bapak Nurul Huda. Menurut data statistic tahun 2014, jumlah penduduk Desa Pekalongan mencapai 2.854 jiwa. Yang berjenis kelamin laki-laki berjumlah 1.442 jiwa (50,53 \%) dan yang berjenis kelamin perempuan berjumlah 1.412 jiwa $(49,47 \%)$.

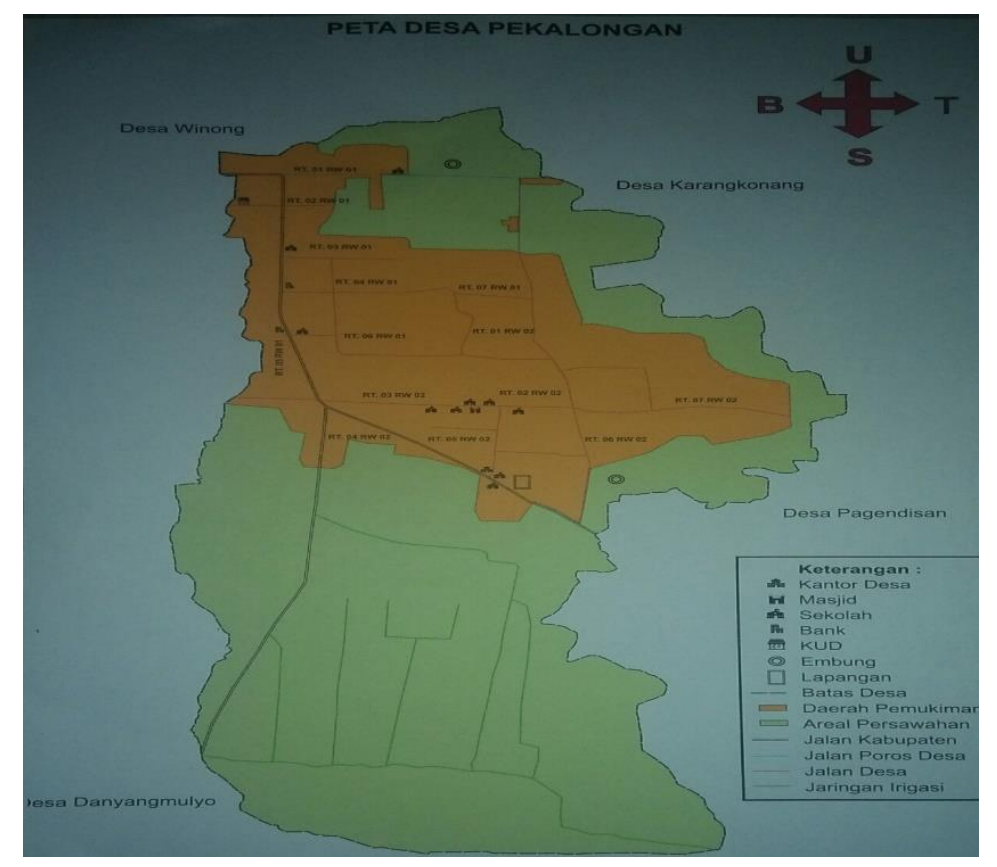

Gambar 1. Peta Desa Pekalongan Kecamatan Winong Kabupaten Pati

Desa Pekalongan terkenal dengan warganya yang terpelajar. Walaupun untuk hidup seharihari saja warganya masih ada yang serba kekurangan, tetapi untuk pendidikan tidak boleh berkurang. Kalau perlu, utang pun dilakukan. Hampir sulit mencari pemuda-pemudi desa ini yang tidak melanjutkan pendidikan sampai ke jenjang perguruan tinggi. Tidak heran bila pernah berdiri organisasi bernama Forum Komunikasi Mahasiswa dan Pelajar Pekalongan (FKMPP) tahun 1992 yang diketuai pertama kali oleh Drs. KH. Abdul Kafi, M.Ag. Semangat belajar di desa ini dipengaruhi oleh beberapa faktor:

1. Kuatnya pengaruh yang ditanamkan para pendahulu untuk selalu belajar

Secara formal, pada tahun 1930 telah berdiri lembaga pendidikan di Desa Pekalongan, yaitu Matholi'ul Falah (di kemudian hari berubah nama menjadi Tarbiyatul Banin) yang didirikan oleh KH. Munji dan KH. Mahfudz Salam (ayahanda KH. Sahal Mahfudz) dari Kajen. Pada masa awal, banyak guru dari Kajen dikirim untuk mengajar di Desa Pekalongan, seperti KH. Sanaji dan KH. Ahmad Fahrurrozi. 
Guru-guru itulah yang menanamkan semangat belajar kepada para pemuda kala itu, sehingga menular ke generasi sekarang.

2. Adanya lembaga pendidikan yang jumlahnya cukup banyak untuk skala desa

Ada 2 sekolah tingkat dasar, 2 sekolah tingkat menengah pertama dan 3 sekolah menengah tingkat atas. Tidak ada alasan bagi anak-anak Desa Pekalongan untuk tidak belajar, karena sekolah ada di depan mata. Sekurang-kurangnya mereka bisa menikmati pendidikan sampai tingkat SLTA. Walaupun sekolah yang ada di Desa Pekalongan kebanyakan sekolah agama, tetapi dalam kenyataannya para pemuda-pemudi tidak sedikit yang melanjutkan ke jenjang pendidikan umum, seperti Universitas Gajah Mada, Universitas Diponegoro, Universitas Muria Kudus, Universitas Negeri Semarang, Universitas Airlangga dan Sekolah Tinggi Akuntansi Negara.

Covid-19 adalah penyakit menular yang disebabkan oleh jenis virus Corona yang baru ditemukan. Sejarah Penemuan pada tanggal 31 Desember 2019, World Health Organization (WHO) mendapatkan informasi mengenai kasus pneumonia yang terjadi di kota Wuhan, Provinsi Hubei, Cina. Tanggal 7 Januari 2020, otoritas Cina mengkonfirmasi telah mengidentifikasi virus baru, yaitu virus Corona, yang merupakan famili virus flu, seperti virus SARS dan MERS. Pada 11 Februari 2020, WHO mengumumkan nama virus Corona jenis baru tersebut adalah Corona Virus Disease 2019 (disingkat menjadi Covid-19). (Jaya, 2020). Akibat dari kebijakan tersebut banyak sektor yang lumpuh, misalnya sector ekonomi yang paling utama lumpuh akibat pandemi ini. Selain dari sektor ekonomi yang mengalami dampak, pendidikan juga merupakan salah satu sektor yang juga mengalami langsung dampak pandemi ini. Menurut UNISCO tercatat setidaknya 1,5 miliyar anak usia sekolah yang terkena dampak Covid-19 dari 188 negara termasuk 60 juta diantaranya ada di negara Indonesia. Akibat pendemi ini sekolah-sekolah ditutup, hal ini dilakukan dengan tujuan untuk mencegah penyebaran Covid-19 (Putria, 2020:863)

Berdasarkan latar belakang yang telah diuraikan sebelumnya, solusi pemulihan pendidikan Desa Pekalongan RT 04/RW 02 dengan menjalankan program daring yang dilakukan dengan kegiatan pendampingan belajar dari rumah untuk membangun semangat belajar siswa sekolah dasar, peran orang tua atau pun orang dewasa sangat diperuntunkan demi keberlangsungan belajar dari rumah yang berjalan dengan baik dan kondusif.

\section{METODE PENELITIAN}

Mitra dalam kegiatan ini adalah masyarakat khususnya siswa-siswi tingkatan sekolah dasar Desa Pekalongan Kecamatan Winong Kabupaten Pati Provinsi Jawa Tengah Indonesia. Teknik pengumpulan data yang digunakan dalam artikel ini ialah pendekatan partisipatif (participatory approach), untuk memberikan gambaran tentang pemberdayaan pendampingan belajar dari rumah untuk membangun semangat siswa sekolah dasar di Desa Pekalongan Kecamatan Winong Kabupaten Pati. Sehingga pendekatan ini berorientasi kepada siswa sebagai subyek sekaligus obyek upaya kelangsungan dalam memahami fenomena pemberdayan pendampingan belajar dari rumah yang terjadi secara holistic (utuh) terkait untuk membangun semangat siswa sekolah dasar dengan cara deskripsi analisis secara induktif dalam bentuk kata-kata dan bahasa. Tahapan dalam kegiatan KKN dilakukan dengan (1) identifikasi kebutuhan siswa, (2) perencanaan, (3) pendampingan belajar dari rumah, (4) evaluasi. Pertama tahap indentifikasi kebutuhan masyarakat (orang tua dan siswa) melalui 
wawancara dan observasi yang dilakukan kepada mitra. Kedua, tahap perencanaan dilakukan dengan cara studi literature dan diskusi. Ketiga, kegiatan pendampingan belajar dari rumah, dilakukan dengan beberapa siswa khususnya tingkatan sekolah dasar melalui pendampingan belajar secara tatap muka langsung. Keempat evaluasi dari kegiatan serta mengambil kesimpulan akan pemberdayaan pendampingan belajar dari rumah yang telah dilaksanakan.
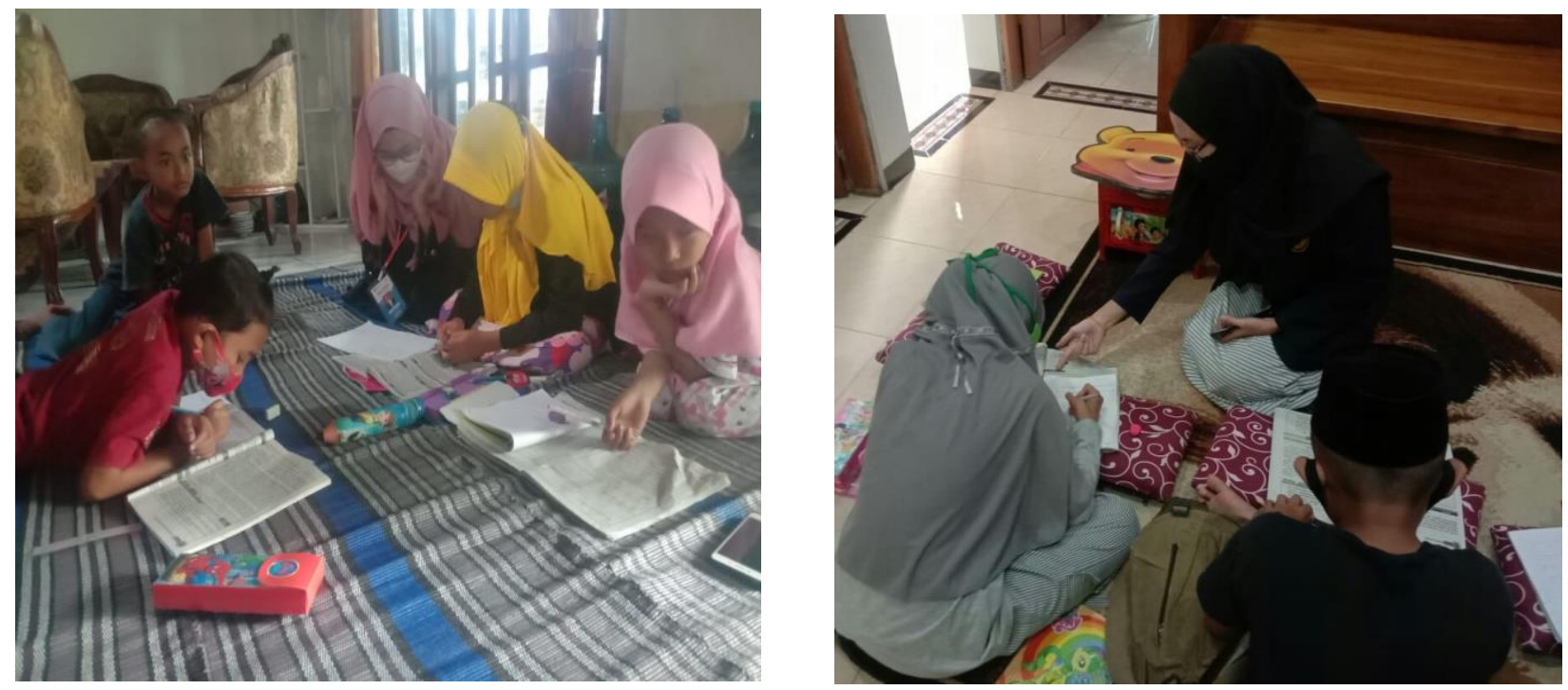

Gambar 2. Proses Kegiatan Pendampingan Belajar di Rumah

\section{HASIL DAN PEMBAHASAN}

pendidikan merupakan proses sepanjang hayat dalam pembentukan diri secara utuh, yang tidak terlepas dalam pengembangan potensi yang dimiliki manusia tiap-tiap individu sebagai mahluk social dan ciptaan Tuhan. Dalam lingkup sebuah pendidikan terjalin dua pihak yang salng terkait, antara lain pihak pendidik dan peserta didik, setiap pihak memiliki peran serta kedudukan masing-masing, namun saling mempengaruhi guna berlangsungnya proses pendidikan.

Tujuan pendidikan menurut UU Sisdiknas No. 20 Tahun 2003, Bab II Pasal 3 bertujuan untuk berkembangnya potensi peserta didik agar menjadi manusia yang beriman dan bertakwa kepada Tuhan Yang Maha Esa, berakhlak mulia, sehat, berilmu, cakap, kreatif, mandiri, dan menjadi warga negara yang demokratis, serta bertanggung jawab. Sehingga dapat disimpulkan bahwa, tujuan pendidikan nasional merupakan sebuah upaya memperluas serta memberikan pemerataan pendidikan bermutu tinggi bagi seluruh warga negara Indonesia secara optimal. Maka dari itu belajar adalah proses aktif yang membutuhkan bimbingan dan dorongan, dari pendidikan diharapkan tumbuh anak-anak didik bangsa Indonesia ini yang berkepribadian tangguh dalam mendukung dan melaksanakan pengembangan pembangunan nasional. Di sisi pendidikan juga diharakan mampu mengembangkan sikap, nilai, moral, dan keterampilan hidup bermasyarakat dalam rangka mempersiapkan warga negara yang berkualitas.

Belajar dari rumah merupakan proses pembelajaran yang dilakukan secara jarak jauh atau terbatas antara guru dengan siswa dengan membutuhkan perantara alat penunjang aplikasi online atau bisa dikatan pembelajaran dalam jaringan, serta pelaksanaanya dilakukan oleh kesepatakan antara guru dan 
siswa dalam proses pembelajarannya. Belajar dari rumah sering disebut pembelajaran daring. Pembelajaran daring pada dasarnya adalah pembelajaran yang dilakukan secara virtual melalui aplikasi virtual yang tersedia (Syarifudin, 2020). Walaupun demikian, pembelajaran daring harus tetap berlangsung secara semestinya, seperti pembelajaran yang dilakukan di kelas, hanya saja dalam hal ini dalam bentuk kelas online.

Pendampingan belajar melalui usaha bimbingan belajar yang diperuntunkan oleh siswa untuk menunjang prestasi akademiknya melalui kegiatan pemberdayaan pendampingan program belajar dari rumah. Bimbingan belajar di rumah sebagai salah satu cara alternatif untuk meningkatkan prestasi dan motivasi siswa dengan mendukung peran partsipasi orang tua, dewasa dan siswa sendiri dalam menumbuhkan semangat keberlangsungan siswa sekolah dasar di Desa Pekalongan RT 04/RW 02 Kecamatan Winong Kabupaten Pati. Guna menunjang terselenggaranya program belajar dari rumah secara baik dan kondusif.

\section{PENUTUP}

Kegiatan KKN yang telah dilaksanakan di Desa Pekalongan Kecamatan Winong Kabupaten Pati Jawa Tengah sudah berjalan dengan baik dan sudah mampu memberikan edukasi dalam program kerja yang telah terlaksanakan. Kegiatan pemberdayaan pendampingan belajar di rumah memberikan suatu ruang dalam proses penyadartahuan kepada peran orang tua atau dewasa dalam pentingnya sebuah pendidikan bagi anak atau siswa walau terhalang adanya kondisi masa saat ini yaitu pandemi Covid19 tidak menutup jalannya untuk menimba ilmu, keberlangsungan kebutuhan akan motorik siswa terus berkembang sesuai dengan usia siswa sendiri, sehingga dalam upaya penerapan program belajar dari rumah mampu mengkonstruk pengetahuan-pengetahuan yang didapat dengan kegaiatan pemberdayaan pendampingan belajar siswa yang tidak terbatas akan ruang dan waktu dalam proses keberlangsungan pendampingan belajar tersebut. Kegiatan pendampingan belajar dari rumah diharap mampu untuk membangun semangat belajar siswa di masa pandemi Covid-19 untuk tetap menimba ilmu pendidikan yang anyam.

\section{UCAPAN TERIMA KASIH}

Penulis mengucapkan terima kasih kepada yang bersankutan pihak masyarakat khusunya siswa-siswi sekolah dasar dalam proses terlaksananya kegitan yang telah berjalan dengan baik, serta atas kepercayaan beliau dari salah satu peran aktif dalam aspek pendidikan untuk mengarahkan kami dalam proses kegiatan pendampingan program belajar dari rumah hingga diterima dan dapat dirasakan manfaatnya baik dari siswa sendiri maupun orang tua atau wali siswa itu sendiri. Tak lupa saya ucapkan terima kasih kepada segenap tim (dosen dan mahasiswa) yang terlibat baik dari Universitas PGRI Semarang.

\section{DAFTAR PUSTAKA}

[1] Jaya, Selviana Indah. 2020. "Mengenal Covid-19”. Diakses dari laman https://vivahealth.co.id/article/detail/13439/mengenal-covid-19 pada 2 Mei 2020 
[2]Kurniasari, Asrilia dkk. 2020. “Analisis Efektifitas Pelaksanaan Belajar Dari Rumah (BDR) Selama Pandemi Covid-19”. Dalam Jurnal Kajian Pendidikan dan Hasil Penelitian vol. 6. No. 3. 2020. Surabaya.

[3] Putria, Hilna dkk. 2020. "Analisis Proses Pembelajran Dalam Jaringan (DARING) Masa Pandemi COVID-19 pada Guru Sekolah Dasar”. Dalam Jurnal Basicedu vol. 4. No. 4. 2020. Sukabumi.

[4] Syarifudin, A. S. (2020). Impelementasi Pembelajaran Daring Untuk Meningkatkan Mutu Pendidikan Sebagai Dampak di Terapkannya Social Distancing. METALINGUA:Jurnal Pendidkan Bahasa dan Sastra Indonesia, 31-34. 